\title{
Uma eucaristia viva para uma Igreja viva: reflexões em torno a um discurso do Papa Francisco ${ }^{1}$
}

\author{
A living Eucharistic for a living Church: \\ Reflections based on a discourse by Pope Francis
}

Francisco Taborda

\section{Resumo}

Para discorrer sobre a relação Igreja - eucaristia na teologia do Papa Francisco, partimos do discurso dirigido por ele aos participantes da $68^{\mathrm{a}}$ Semana Litúrgica Nacional, promovida pela Conferência Episcopal Italiana. Ele aborda o tema da Semana ("Uma liturgia viva para uma Igreja viva") em três momentos que determinam a divisão do presente trabalho: a liturgia é viva graças à presença de Cristo; a liturgia é vida de todo o povo de Deus (Igreja), requer participação; a liturgia é vida, porque evento experiencial a ser traduzido na prática ("Não há eucaristia sem lava-pés").

Palavras-chave: Igreja e eucaristia. Papa Francisco. Presença de Cristo. Participação litúrgica. Vida cristã.

\footnotetext{
${ }^{1}$ Conferência pronunciada no Simpósio Internacional sobre a eclesiologia do Papa Francisco, promovido pela Sociedade Brasileira de Teologia Sistemática (SBTS), realizado no Mosteiro de São Bento, Rio de Janeiro, de 7 a 9 de setembro de 2017. - A bibliografia sobre os diversos aspectos do pontificado do Papa Francisco é imensa. Recordem-se alguns títulos a que tive acesso: FRANÇA MIRANDA, M. A reforma de Francisco: fundamentos teológicos. São Paulo: Paulinas, 2017. AUGUSTIN, G. La Chiesa secondo Papa Francesco. Milano: Paoline, 2016. D'AMBROSIO, R. Ce la fará Francesco? La sfida della riforma ecclesiale. Molfetta (BA): La Meridiana, 2016. GONZÁLEZ-QUEVEDO, L. O novo rosto da Igreja: Papa Francisco. $4^{\mathrm{a}}$ ed. corrigida e ampliada. São Paulo: Loyola, 2015.
} 


\begin{abstract}
To talk about Church - Eucharist relation in the theology of Pope Francis, we begin from the speech he delivered to the participants of the $68^{\text {th }}$ National Week of Liturgy, which was organized by the Italian Episcopal Conference. He approaches the theme of the week (a living Liturgy for a living Church) in three determining moments, this present work follows his sequence: the liturgy is "living" by reason of the living presence of Christ; the liturgy is life for the entire people of God (the Church), it requires participation; the liturgy is life, because it is an experiential event to be rendered in practice ("there is no Eucharist without washing of the feet").
\end{abstract}

Keywords: Church and Eucharist. Pope Francis. Presence of Christ. Liturgical Participation. Christian life.

\title{
Introdução
}

A 24 de agosto de 2017, em audiência aos participantes da $68^{\text {a Semana }}$ Litúrgica Nacional, promovida pela Conferência Episcopal Italiana, o Papa Francisco pronunciou um discurso que se poderia chamar de programático para seu pensamento a respeito da liturgia.

Numa primeira parte do discurso o Papa discorre sobre a longa preparação da reforma litúrgica instaurada pelo Concílio Vaticano II, partindo de Pio X e mostrando o extenso percurso que desaguou na Constituição Sacrosanctum Concilium, fruto maduro de uma longa e pensada evolução. O Papa se pronuncia claramente contra intentos de reverter a obra do Vaticano II sob o slogan de uma "reforma da reforma". "Não se trata de repensar a reforma, revendo suas opções, mas de conhecer melhor as razões subjacentes, também por meio da documentação histórica, como de interiorizar seus princípios inspiradores e de observar a disciplina que a regula". ${ }^{2}$ E conclui solenemente: "Depois deste magistério [de Pio X ao Vaticano II], depois deste longo caminho, podemos

\footnotetext{
2 PAPA FRANCISCO. "Audiência aos participantes da $68^{\mathrm{a}}$ Semana Litúrgica Nacional, 24.08.2017”. Disponível em: <http://press.vatican.va/content/salastampa/it/bollettino/ pubblico/2017/08/24/0531/01182.html>. Acesso em 25 de agosto de 2017.
} 
afirmar com segurança e com autoridade magisterial que a reforma litúrgica é irreversivel". ${ }^{3}$

Interessa ao nosso propósito a segunda parte do discurso, em que o Papa reflete sobre o tema da Semana Litúrgica: "Uma liturgia viva para uma Igreja viva" e, portanto, relaciona Igreja e liturgia. São três pontos que também constituirão a divisão do presente trabalho: a liturgia é viva graças à presença de Cristo; a liturgia é vida de todo o povo de Deus (Igreja); a liturgia é vida, porque evento experiencial.

Talvez se possa objetar que o Papa fala neste discurso de liturgia e não de eucaristia. Entretanto, não se pode esquecer que a eucaristia é a ação litúrgica por excelência. Não sem razão a celebração que a Igreja latina durante séculos chamou e ainda hoje continua a chamar de "missa" é - mais adequadamente designada pelas Igrejas Orientais "Divina Liturgia". De fato, se liturgia, como diz a Constituição Litúrgica, é o "exercício da função sacerdotal de Cristo" e nela se realiza a santificação dos seres humanos que por ela prestam culto a Deus (cf. SC 7), obviamente é de forma especial na eucaristia que a liturgia tem o seu ponto culminante e central. E o Papa acrescenta, inspirando-se no Concílio: "O que define a liturgia é a atuação, nos santos sinais, do sacerdócio de Jesus Cristo, ou seja, a oferta de sua vida até estender os braços na cruz, sacerdócio tornado presente de modo constante através dos ritos e das orações, maximamente em seu Corpo e Sangue". ${ }^{4}$

Se o tema da Semana Litúrgica era "Uma liturgia viva para uma Igreja viva", este trabalho sobre Igreja e eucaristia no magistério do Papa Francisco poderia ser intitulado "Uma eucaristia viva para uma Igreja viva". A vida da Igreja é constituída pela presença de Cristo que prometeu estar com seus discípulos "todos os dias até o fim dos tempos" (Mt 28,20). E a forma máxima dessa presença se dá, como diz o Concílio, «no sacrifício da missa, quer na pessoa do ministro - pois "quem agora se oferece pelo ministério dos sacerdotes é o mesmo que então se ofereceu na cruz" (DH 1743 ) -, quer especialmente sob as "espécies eucarísticas" (SC 7; DH 4007). É o tema da primeira parte do artigo: Presença atuante de Cristo na Igreja e na eucaristia.

O segundo aspecto abordado pelo Papa Francisco é que "a liturgia é vida

3 PAPA FRANCISCO. “Audiência aos participantes da $68^{\mathrm{a}}$ Semana Litúrgica Nacional, 24.08.2017” (grifo meu).

${ }^{4}$ PAPA FRANCISCO. "Audiência aos participantes da $68^{\mathrm{a}}$ Semana Litúrgica Nacional, 24.08.2017" (grifo meu). 
para todo o povo da Igreja". ${ }^{5}$ Ele acentua que a liturgia é fator de comunhão e faz ele próprio explicitamente a transposição para a eucaristia, citando sua homilia na solenidade de Corpus Christi deste ano de 2017: “A eucaristia não é um sacramento 'para mim', é o sacramento dos muitos que formam um só corpo, o santo povo fiel de Deus". ${ }^{6}$ Daí o título da segunda parte deste artigo: A eucaristia, ação de Cristo, cabeça e membros.

$\mathrm{O}$ terceiro aspecto é que a liturgia é a vivência de uma experiência iniciática e transformadora. Daí a terceira parte intitulada: A eucaristia, escola de vida cristã, vale dizer: de vida eclesial.

\section{Presença atuante de Cristo na Igreja e na eucaristia}

Um dos textos mais significativos da Sacrosanctum Concilium é a afirmação da presença de Cristo nas ações litúrgicas, apresentada no artigo 7 da Constituição. Ainda durante o recesso entre a terceira e a quarta sessão do Concílio, Paulo VI, na encíclica Mysterium fidei, de 3 de setembro de 1965, ${ }^{7}$ complementou a lista, explicitando formas de presença de Cristo fora da ação litúrgica, na vida cotidiana dos cristãos e da Igreja.

Esses dois textos do magistério sugerem que se relacionem os dois âmbitos da presença de Cristo: na liturgia (e obviamente na eucaristia) e na Igreja. Mas antes convém repensar o que significa presença.

Presença não é mero estar ai. ${ }^{8}$ Não significa primeiramente a coexistência física de dois corpos em espaços contíguos. Posso estar fisicamente muito perto de alguém e, no entanto, estar longe, ausente. Se a presença fosse, em primeiro lugar, um fenômeno físico, a presença mais densa seria a presença mútua entre as pessoas que lotam o ônibus nas horas de trânsito mais intenso. E não é. Aí justamente é onde há menos presença no sentido profundo da

\footnotetext{
5 PAPA FRANCISCO. "Audiência aos participantes da $68^{\mathrm{a}}$ Semana Litúrgica Nacional, 24.08.2017” (grifo meu).

${ }^{6}$ PAPA FRANCISCO. "Homilia na festa do Santíssimo Corpo e Sangue de Cristo, 18.06.2017". Disponível em: <http://w2.vatican.va/content/francesco/it/homilies/2017/documents/papafrancesco_20170618_omelia-corpus-domini.html>. Acesso em 27 de agosto de 2017.

${ }^{7}$ Cf. PAPA PAULO VI. "Encíclica Mysterium fidei, 03.09. 1965". Disponível em: <http://www. vatican.va/holy_father/paul_vi/encyclicals/documents/hf_p-vi_enc_03091965_mysterium po.html>. Acesso em 30 de setembro de 2012. Para uma avaliação equilibrada dessa encíclica, cf. EISENBACH, F. Die Gegenwart Jesu Christi im Gottesdienst: systematische Studien zur Liturgiekonstitution des II. Vatikanischen Konzils. Mainz: Matthias-Grünewald, 1982, pp. 635-649.

${ }^{8}$ Cf. TABORDA, F. O memorial da Páscoa do Senhor: ensaio litúrgico-teológicos sobre a eucaristia. $2^{\text {a }}$ ed. São Paulo: Loyola, 2015, pp. 272-273.
} 
palavra. Um está ao lado do outro, quase corpo a corpo com o outro, e, no entanto, bem distante daquele que está a seu lado.

Presença, no seu sentido antropológico, não é estar junto ao outro, mas estar/ser para o outro. Nesse sentido posso estar fisicamente distante do outro e, no entanto, o outro me é presente pela recordação, pelo pensamento, por algum objeto que o recorda. A presença espaço-temporal de dois seres é importante apenas como expressão de uma presença no âmbito mais profundo, especificamente humano. A presença espaço-temporal vale enquanto é expressão do ser um para o outro, do estar um para o outro. O significado originário da palavra "presença" não é a presença física, mas a presença por amor, em espírito, no conhecimento, na ação... Tal modo de falar em presença não é simplesmente metafórico e secundário; é o modo verdadeiro e real de estar presente.

No caso da presença de Cristo, do Cristo Ressuscitado, não se pode esquecer que ela acontece no Espírito Santo. É o Espírito que atua a presença de Cristo em todas as suas formas. O teólogo oriental Inácio Hazim, posteriormente patriarca ortodoxo de Antioquia, na IV Assembleia do Conselho Mundial de Igrejas, em Upsala (Suécia), 1968, pronunciou a respeito palavras inspiradoras:

Sem o Espírito Santo, Deus está distante, Jesus Cristo fica no passado, o Evangelho é letra morta, a Igreja, uma simples organização, a autoridade, um despotismo, a missão, uma propaganda, o culto, uma simples recordação, o agir, uma moral de escravos. No Espírito, porém, e em sua sinergia indissociável, o cosmo se levanta e geme até que dê à luz o Reino, o homem luta contra a carne, Cristo Ressuscitado está aqui presente, o Evangelho é poder de vida, a Igreja significa a comunhão trinitária, a autoridade é um serviço libertador, a missão, um novo Pentecostes, a liturgia, um memorial e uma antecipação, o agir humano é divinizado. ${ }^{9}$

\subsection{Presença de Cristo na Igreja}

Numa frase concisa e densa, o Decreto Christus Dominus do Concílio Vaticano II expressa o que constitui uma Igreja particular como Igreja: é a

\footnotetext{
${ }^{9}$ HAZIM, I. "La Réssurrection et l'homme d'aujourd'hui". Beirut, 1970, p. 31, citado em: CODINA, V. "Não extingais o Espírito" (1Ts 5,19): iniciação à pneumatologia. São Paulo: Paulinas, 2010, pp. 71-72.
} 
porção do Povo de Deus, unida a seu bispo e, pelo ministério deste, reunida no Espírito Santo por meio do Evangelho e da eucaristia (CD 11). ${ }^{10}$

Afirmar que Evangelho e eucaristia reúnem a Igreja no Espírito Santo pelo ministério é reconhecer que é a presença de Cristo, através da ação do Espírito, que constitui verdadeiramente a Igreja como tal. Vale dizer: a Igreja não é criada pelo ser humano, membro da Igreja, que resolve reunir-se - nem mesmo pela ação dos pastores -, mas por Cristo que se expressa e expressa 0 mistério de Deus ao mundo por esta comunidade, cuja missão é - reunida ou dispersa - proclamar a vitória de Cristo sobre a morte. É Cristo no Espírito Santo que continua a criar a Igreja como forma de presença, assim como ele a criou outrora, dando-se a reconhecer ressuscitado aos primeiros discípulos e enviando sobre eles o Espírito em Pentecostes.

A partir desta fé criou-se o axioma teológico ubi Ecclesia, ibi Christus (onde a Igreja, aí está o Cristo), que poderia também ser invertido: ubi Christus, ibi Ecclesia (onde Cristo, aí está a Igreja). Este axioma, muitas vezes atribuído genericamente aos Padres da Igreja, sem especificar a fonte, baseiase em última análise num famoso texto de Inácio de Antioquia ( $†$ antes de 117) em sua carta à Igreja de Esmirna: "Onde se mostra o bispo, aí esteja a comunidade [ $\pi \lambda \hat{\eta} \theta 0 \mathrm{~s}=$ a multidão], como onde está o Cristo Jesus, ali está a Igreja católica" ${ }^{11}$ Semelhantemente diz Ambrósio de Milão: "Crê, pois, que está presente, invocado pelas preces dos sacerdotes, o Senhor Jesus, que diz: Onde quer que estejam dois ou três, aí também eu estou. Quanto mais então onde está presente a Igreja, onde estão seus mistérios, se digna ele concedernos sua presença!". ${ }^{12}$

Reunida ou dispersa, a Igreja - nós, cristãos - é sempre sinal eficaz da presença de Cristo. As quatro formas de presença que Paulo VI, na encíclica Mysterium fidei, acrescenta à presença litúrgica ensinada pela Sacrosanctum Concilium, dizem respeito a essa presença cotidiana de Cristo na Igreja: presença na prática das obras de misericórdia, pois é a Cristo que socorremos no necessitado e é o próprio que, por nosso ministério, socorre o pobre;

\footnotetext{
${ }^{10}$ Cf. TABORDA, F. Nas fontes da vida cristã: uma teologia do batismo-crisma. $3^{\text {a }}$ edição revisada. São Paulo: Loyola, 2012, pp. 225-227. TABORDA, F. A Igreja e seus ministros: uma teologia do ministério ordenado. $2^{\mathrm{a}}$ reimpressão. São Paulo: Paulus, 2016, pp. 141-144.

${ }^{11}$ INÁCIO DE ANTIOQUIA. Carta aos esmirniotas 8,2 (SChr 10, 162-163). Tradução brasileira: Cartas de Santo Inácio de Antioquia: comunidades eclesiais em formação. $2^{\mathrm{a}}$ ed. Petrópolis: Vozes, 1978.

12 AMBROSIO DE MILÃO. Os mistérios 5,27 (SChr 25, 115-116). Tradução brasileira: Os sacramentos e os mistérios. Petrópolis: Vozes, 1972.
} 
presença na fé, na esperança e na caridade (MF 35); presença na pregação do Evangelho (MF 36) e no governo da Igreja (MF 37).

A presença de Cristo na Igreja se manifesta no seguimento do Senhor, o que se mostra - como se vê nos sumários dos Atos do Apóstolos - porque seus membros têm tudo em comum, tomam as refeições com alegria, mostram seu amor aos enfermos (curas) e aos pobres (At 6,1)... A Igreja se manifesta como Igreja agindo como ele agiu, vale dizer: criando fraternidade a partir do pobre. Num mundo conflitivo, dividido (como o de Jesus era entre fariseus e publicanos, "justos" e "pecadores", ricos e pobres... e como é o nosso entre opressores e oprimidos), constrói-se fraternidade na solidariedade com o pobre. ${ }^{13}$ Toda fraternidade que não se baseie nessa solidariedade é falsa, pseudofraternidade, porque é abstrata, não tem base concreta (cf. $\operatorname{Tg} 2,14-17$ ). A solidariedade com os pobres é lugar de verificação da fidelidade da Igreja a Jesus. Onde isso não acontece a Igreja não manifesta a presença do Senhor. À semelhança do que Paulo diz da eucaristia dos coríntios, ela não é a "Igreja do Senhor" (cf. 1Co 11,17-34: "não é a ceia do Senhor"). ${ }^{14}$

Só se compreende a Igreja em seu ser mais profundo a partir da ressurreição, como participação na ressurreição, comunidade de fé que pertence intrinsecamente à ressurreição. ${ }^{15}$ Ora, se é assim, é com respeito à Igreja que se compreende Mt 28,20: "Eis que estou convosco todos os dias até a consumação dos séculos". A Igreja é presença do Ressuscitado, mas sendo o outro do Ressuscitado. Vale dizer: a Igreja medeia a presença do Ressuscitado, mas não é o próprio Ressuscitado. Ela é, pela ação do Espírito, que é Espírito do Cristo Ressuscitado, sacramento de Cristo. Nela o Cristo está presente, mas, sendo santa e pecadora, casta e meretriz, fiel e infiel, a presença de Cristo é maior que a Igreja. Fazer memória de Cristo é, para ela, desafio à fidelidade, repto a que seja aquilo que ela deve ser. E, no entanto, a presença de Cristo, maior que a Igreja, é mediada pela Igreja. Por isso mesmo é presença pelo seguimento, pela Palavra, pelo sacramento. Três manifestações nas quais a Igreja se subordina a Cristo: subordina-se no seguimento, pois toma o Cristo (diferente dela) por norma, por "autor e realizador da fé" (Hb 12,2); subordinase ao ouvir a Palavra, pois a Igreja esta $s o b$ a Palavra de Deus; subordina-se

\footnotetext{
${ }^{13}$ Cf. TABORDA, F. Cristianismo e ideologia: ensaios teológicos. São Paulo: Loyola, 1984, passim (p. ex.: pp. 202-208).

${ }^{14}$ Sobre o pano de fundo social de 1Cor 11, cf. THEISSEN, G. Sociologia da cristandade primitiva: estudos. São Leopoldo: Sinodal, 1985, pp. 148-167.

${ }^{15}$ Cf. TABORDA. O memorial da Páscoa do Senhor, pp. 259-261.
} 
ao celebrar os sacramentos, pois a Igreja é servidora dos sacramentos, não senhora.

Os modos de presença de Cristo na Igreja que podem ser resumidos nesta tríade, embora possam ser mais detalhados, são na verdade especificações $d a$ presença que resulta do fato de a Igreja ser momento intrínseco da ressurreição, corpo do Ressuscitado. Mas exatamente por não se identificar pura e simplesmente com a Igreja, mas a transcender, Cristo tem uma presença entre nós que é, de certa forma, "anterior" à presença na Igreja e é onde se verifica a verdade da presença dele na Igreja: é a presença de Cristo no pobre (cf. Mt. 25, 40).

A presença de Cristo na Igreja possibilita que se abram os olhos para sua presença no pobre. Esta é "primeira", anterior à fé e à pregação (no sentido de que alguém pode estar fechado à presença de Cristo na Igreja, não conseguir ou não querer reconhecê-la, mas não pode escapar à presença de Cristo no pobre, que é juízo, de cujo reconhecimento pende a salvação). É o que nos mostra a parábola do juízo final Mt 25,31. ${ }^{16}$ Não são cristãos os que vão ser julgados, mas "todas as nações" (v. 32), que não conhecem a Jesus (cf. v. $37-39$; v. 44). Essa presença é tão objetiva quanto o próprio pobre (não que a presença na Igreja não seja objetiva, mas nela deve entrar o reconhecimento explícito: a Igreja é comunidade de fé).

Sendo a presença de Jesus no pobre logicamente "anterior" à presença na Igreja, ela é a medida da verdade da presença de Cristo na Igreja, isto é, a presença de Cristo na Igreja se mostrará verdadeira na medida em que a Igreja reconhecer a presença de Cristo no pobre, presença distinta dela e que mostra que Jesus é mais do que ela, a Igreja.

Reconhecer a presença de Cristo no pobre traz como consequência que a Igreja se deve tratar de identificar com o pobre, solidarizar-se com ele, assumir sua causa (dar de comer, de beber, vestir, visitar ...); em outras palavras: ser a Igreja dos pobres. Solidarizar-se é dar e receber mutuamente: a Igreja recebe dos pobres pela solidariedade que lhes presta (e, portanto, os pobres dão à Igreja) a verdade da presença do Senhor, a prova messiânica de sua missão (a missão messiânica é acudir ao pobre), a autenticação da eclesialidade; os pobres recebem da Igreja (e, portanto, a Igreja dá aos pobres) a boa nova do Reino, o conhecimento do Deus verdadeiro e de seu enviado Jesus Cristo.

${ }^{16}$ Cf. KONINGS, J. “Quem é quem na 'parábola do último juízo' (Mt 25, 31-46)?” Perspectiva Teológica 10 (1978), pp. 367-402. 
Reconhecer a presença de Cristo no pobre é condição de possibilidade e de verificação da presença de Cristo na Igreja. Quer dizer: a Igreja mostrase Igreja, quando reconhece a Jesus no pobre. Do contrário se esvazia da presença de Jesus (porque já não crê).

Com isto já é possível passar à segunda forma de presença de Cristo à Igreja que Paulo VI explica da seguinte maneira:

Está presente à sua Igreja enquanto esta peregrina e anseia por chegar ao porto da vida eterna: habita nos nossos corações por meio da fé (cf. Ef 3,17 ), e neles difunde a caridade por meio da ação do Espírito Santo, que nos dá (cf. Rm 5,5) (MF 35).

Com isso remete às três virtudes teologais, referindo-se a elas na ordem: esperança, fé e caridade.

Ao mencionar a ação do Espírito Santo, Paulo VI fornece a chave de compreensão da presença de Cristo na prática dessas virtudes. Se é o Espírito que difunde em nós a caridade, se é pela fé que Cristo habita em nós, se a esperança é o que anima nossa peregrinação rumo ao Pai, é no Espírito Santo que tudo isso acontece. A piedade de nossos irmãos de tradição bizantina, sejam ortodoxos, sejam católicos, acentua, com razão, essa presença de Cristo pelo Espírito Santo através da recitação da oração "Rei celestial":

Rei celestial, Consolador, Espírito da verdade, presente em toda parte e ocupando todo lugar, tesouro dos bens e dispensador da vida, vem e habita em nós, purifica-nos de toda a mancha e salva, ó Bondoso, as nossas almas!. ${ }^{17}$

Esta prece é de fundamental importância para a espiritualidade cristã oriental, com a prática frequente de recitá-la de manhã, à noite e várias vezes ao dia. Não se pode esquecer que é no Espírito que Cristo está presente, de forma que esta oração é expressão da fé na onipresença do Cristo na vida cristã.

\footnotetext{
${ }^{17}$ A respeito do texto «Rei celestial», cf. PARENTI, S.; VELKOVSKA, E. "“Re celeste, Paraclito, Spirito di Verità': il Veni Creator Spiritus della liturgia bizantina”. In: CARR, E. (Ed.). Spiritus spiritalia nobis dona potenter infundit: a proposito di tematiche liturgico-pneumatologiche. Studi in onore di Achille M. Triacca, sdb. Roma: Centro Studi S. Anselmo, 2005, pp. 387-404. Tradução brasileira do texto litúrgico: SPERANDIO, J. M.; TAMANINI, P. A. (Orgs.). Liturgikon: próprio das principais festas. Teresina: EDUFPI, 2015, p. 87. Disponível em: <https://www.ecclesia.com.br/biblioteca/liturgia/liturgikon2.pdf>. Acesso em $1^{\mathrm{o}} \mathrm{de}$ setembro de 2017.
} 
Paulo VI recorda que Cristo não está presente só na proclamação litúrgica da Palavra, mas também na transmissão da Palavra pela pregação e catequese. O Decreto Ad Gentes, sobre a atividade missionária da Igreja, é explícito: "Pela palavra da pregação e pela celebração dos sacramentos de que a eucaristia é o centro e a máxima expressão, [a atividade missionária] torna presente a Cristo, autor da salvação" (AG 9). A própria atuação da Igreja em sua missão de transmitir o Evangelho só pode ser, pois, compreendida como manifestação de que Cristo continua, através dos séculos, presente e atuante no mundo. Nas palavras de Paulo VI:

Cristo está presente à sua Igreja enquanto ela prega, sendo o Evangelho, assim anunciado, Palavra de Deus, que é anunciada em nome de Cristo, Verbo de Deus Encarnado, e com a sua autoridade e assistência, para que haja "um só rebanho, cuja segurança virá de ser um só o pastor" (MF 36). ${ }^{18}$

Finalmente, lembra a assistência de Cristo - diríamos completando: através do Paráclito prometido - enquanto a Igreja "dirige e governa o povo de Deus, porque de Cristo deriva o poder sagrado, e Cristo, 'Pastor dos Pastores', assiste os Pastores que o exercem" (MF 37). Por um lado, deve-se observar neste texto a lacuna pneumatológica da teologia latina, pois, enquanto normalmente se fala da assistência do Espírito Santo, ele aqui não é mencionado pelo Papa. No entanto, toda presença de Cristo se dá no Espírito e sem ele Cristo não está atuante em sua Igreja. Por outro lado, recorde-se que Paulo VI sentia a necessidade de acentuar a ação de Cristo no governo da Igreja que começava a ser contestado em nome da modernidade. Essa polêmica se manifestou, por exemplo, na própria reforma litúrgica, quando, na antífona ao Benedictus das laudes do comum dos pastores, aplica a papas, bispos e presbíteros um texto do sermão missionário do capítulo 10 do Evangelho de Mateus que se refere à inspiração que os cristãos receberiam do Espírito na situação de perseguição (Mt 10,20): "Não sois vós que falareis, é o Espírito do Pai que em vós há de falar". ${ }^{9}$

Essas formas de presença de Cristo na vida cotidiana da Igreja (entendida como o conjunto dos cristãos) não devem ser separadas das formas de presença

\footnotetext{
${ }^{18} \mathrm{Na}$ citação de Paulo VI, o trecho entre aspas é tomado da obra: AGOSTINHO DE HIPONA. Contra a carta do donatista Petiliano, bispo de Cirtes, livro 3, capítulo 10 (PL 43, 353).

${ }^{19}$ LITURGIA DAS HORAS segundo o rito romano. Vol. IV. Petrópolis; São Paulo: Vozes/ Paulinas/Paulus/Ave-Maria, 1999, p. 1759.
} 
nas ações litúrgicas - em especial na eucaristia - que o Concílio afirmara e Paulo VI recalca em sua encíclica.

\subsection{Presença de Cristo na eucaristia}

Ao afirmar a presença de Cristo nas ações litúrgicas, o Concílio é, de certa forma redundante, no que concerne à eucaristia. De fato, as quatro (ou cinco - conforme se conte) formas de presença são: 1) no sacrifício da Missa, sob dois aspectos: na pessoa do ministro e especialmente sob as espécies eucarísticas; 2) nos sacramentos, de modo que, quando alguém batiza, é o próprio Cristo que batiza; 3) na sua Palavra; 4) quando a Igreja reza e canta (cf. SC 7; DH 4007).

Na preocupação por não causar estranheza - pois este foi um dos textos mais discutidos na elaboração da Constituição Litúrgica - salienta-se de modo especial a presença real de Cristo sob as espécies de pão e de vinho.

$\mathrm{O}$ outro aspecto referente à eucaristia é a presença de Cristo na pessoa do ministro, que não seria preciso salientar, pois está incluída na segunda forma de presença, onde também se trata da presença de Cristo no ministro. Enquanto no primeiro caso se tem em mente a tradicional fórmula, segundo a qual quem preside a eucaristia age in persona Christi, ${ }^{20}$ no segundo, evoca-se a polêmica agostiniana contra os donatistas, remetendo em nota de rodapé a um texto de Agostinho em seu comentário ao Evangelho de João ${ }^{21}$. Entretanto, em ambos os casos, se trata da afirmação de que a eficácia do sacramento não depende da santidade do ministro, mas da atuação de Cristo no Espírito Santo. O olvido do Paráclito na teologia latina fez com que ele fosse mencionado indiretamente na alusão à força de Cristo. Mas o que é - ou melhor: quem é - a força de Cristo senão o Espírito?

Também reforça a presença de Cristo na eucaristia a terceira afirmação: na sua Palavra, "pois é ele que fala quando na Igreja são lidas as Sagradas Escrituras". Esta fé da Igreja se manifesta no fato de, em todas as famílias litúrgicas, ressaltar-se a proclamação do Evangelho como ponto culminante da liturgia da Palavra. ${ }^{22}$ Ela está no centro da liturgia da Palavra, pois no

\footnotetext{
${ }^{20} \mathrm{Cf}$. MARLIANGEAS, B. D. Clés pour une théologie du ministère: in persona Christi, in persona Ecclesiae. Paris: Beauchesne, 1978. TABORDA. A Igreja e seus ministros, pp. 160-162. ${ }^{21}$ Cf. AGOSTINHO DE HIPONA. Comentário ao Evangelho do João, tratado 6, 1, n. 7 (PL $35,1428)$.

${ }^{22}$ Para o que se segue, cf. TABORDA. O memorial da Páscoa do Senhor, pp. 155-156.
} 
Evangelho se nos apresenta Jesus, a própria Palavra feita carne, expressandose em palavras e ações e, portanto, manifestando o Pai, do qual ele é a

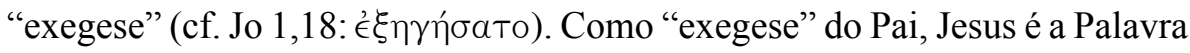
viva de Deus em pessoa. A partir de suas palavras e ações o cristão lê o Antigo Testamento (primeira leitura); e é sobre o evento narrado nos Evangelhos que falam os demais livros do Novo Testamento (segunda leitura que, na linguagem litúrgica, é muitas vezes designada simplesmente "o Apóstolo").

Pode-se reconhecer esse destaque, também considerando o ministro a quem cabe proclamar o Evangelho e tendo presentes os gestos que acompanham a proclamação. O ministro é o diácono, cuja função na Igreja é a concretização do Evangelho a partir dos pobres, ${ }^{23}$ Para proclamá-lo recebe a bênção do bispo (ou presbítero) que preside a celebração. ${ }^{24}$

Os ritos que cercam a proclamação do Evangelho igualmente destacam sua posição central na liturgia da Palavra. Em todas as liturgias, ele é escutado de pé, na atitude escatológica de prontidão para acolher o Cristo que vem a nosso encontro e nos fala nas narrativas evangélicas. O evangeliário é introduzido solenemente em procissão (procissão do Evangelho), trazido pelo diácono ou outra pessoa, acompanhado de velas e, dado o caso, de incenso. Colocado sobre o altar, expressa que é Cristo (o altar é Cristo!) quem fala, e ao evangeliário cabem as honras devidas ao próprio Cristo (daí as velas e o incenso, o canto e a acolhida de pé, como o beijo no final da proclamação). A proclamação é, por sua vez, introduzida pela saudação litúrgica máxima, "O Senhor esteja convosco" Precisamos que o Senhor esteja conosco para podermos acolher sua Palavra, como o ministro precisa da graça do Senhor para proclamá-la ("E contigo também", "E com teu Espírito"). ${ }^{25}$ Assim como foi aclamado com o canto do aleluia ao entrar, ao ser anunciada sua leitura ("Do Evangelho segundo NN") é novamente aclamado: "Glória a vós, Senhor". Ao ser introduzida a proclamação tanto quem proclama, como todos os fiéis se persignam. Essa cruz marcada no livro, na fronte, nos lábios e no coração indica que queremos ouvir a Palavra de Cristo, consignada neste livro, com a

\footnotetext{
${ }^{23}$ Cf. TABORDA. A Igreja e seus ministros, pp. 200-206.

${ }^{24}$ À medida que foi desaparecendo o diaconado na Igreja Latina, o próprio presidente da celebração assumiu a proclamação do Evangelho e passou a pronunciar sobre si mesmo a bênção para bem proclamá-lo. Ela se torna assim uma das tantas orações privadas para a piedade pessoal do «celebrante».

${ }^{25}$ Cf. TEODORO DE MOPSUÉSTIA. Homilia 15 (Primeira homilia sobre a missa), $\mathrm{n}^{\mathrm{o}}$ 36-38. In: THÉODORE DE MOPSUESTE. Homélies catéchétiques. Paris: Migne, 1996, p. 261. FLORO DE LYON (†860). Explicação da missa, 12-13 (PL 119,26).
} 
mente aberta, confessá-la com a boca e, principalmente, conservá-la fielmente no coração. ${ }^{26}$ Em todo o ritual em torno ao Evangelho a atenção não se dirige ao livro, mas ao Senhor Jesus que vai falar. Também no final, é repetida a aclamação «Glória a vós, Senhor» ${ }^{27}$.

$\mathrm{Na}$ liturgia romana a piedade medieval acrescentou uma oração pessoal do ministro que leu o Evangelho (a ser pronunciada em voz baixa, portanto): "Pelas palavras do Santo Evangelho sejam perdoados os nossos pecados", ${ }^{28}$ pedido cheio de sentido, pois expressa que a leitura/escuta da Palavra de Deus pertence às formas cotidianas de perdão. ${ }^{29}$ Seria também significativo se, no final do Evangelho, depois de venerar o evangeliário com o beijo, aquele que preside a celebração da eucaristia - e não apenas o bispo - abençoasse a assembleia com o livro que contém as palavras e ações de Cristo. O Senhor Jesus, que falou no Evangelho e cuja presença é simbolizada pelo evangeliário, abençoa o povo.

Também, a quarta forma de presença referida pelo Concílio, a presença de Cristo na assembleia litúrgica, vale evidentemente da celebração eucarística e corrige a concepção de considerar Cristo presente tão só a partir das chamadas "palavras da consagração". Alerta para que se tome consciência da presença de Cristo desde o primeiro momento da celebração eucarística. Não em vão várias vezes no decurso da celebração à saudação "O Senhor esteja convosco" se responde com a profissão de fé "Ele está no meio de nós". ${ }^{30}$ Recorda que a presença de Cristo não acontece só por aquele que a preside, mas por toda a assembleia concelebrante. ${ }^{31}$ A tradição litúrgica o expressa claramente ao

${ }^{26}$ Cf. JUNGMANN, J. A. Missarum sollemnia: origens, liturgia, história e teologia da missa romana. $2^{\mathrm{a}}$ ed. Petrópolis: Vozes, 2010, p. 442.

${ }^{27} \mathrm{Na}$ tradução brasileira oficial; em latim reza, no início, Gloria tibi, Domine (Glória a vós, ó Senhor) e, no final do Evangelho, Laus tibi, Christe (Louvor a vós, ó Cristo).

${ }^{28}$ No original latino, constitui um versinho rimado: «Per evangelica dicta, deleantur nostra delicta».

${ }^{29}$ Cf. TABORDA, F. "Penitência cotidiana: uma verdade a ser recordada". Revista Eclesiástica Brasileira 76 (2016) pp. 401-411.

${ }^{30}$ Esta afirmação vale somente da tradução brasileira do Missal Romano.

${ }^{31}$ A propósito, leve-se em consideração a advertência tuciorista da Congregação do Culto Divino e da Disciplina dos Sacramentos na Instrução Redemptionis Sacramentum, de 25.03.2004, $\mathrm{n}^{\circ} 42$, sobre o uso das locuções «comunidade celebrante ou assembleia celebrante». Disponível em: <http://www. vatican.va/roman_curia/congregations/ccdds/documents/rc_con_ccdds_doc_20040423_redemptionis-sacramentum_lt.html $>$. Acesso em 30 de agosto de 2017. Entretanto, é imprescindível prestar atenção ao magistério da Igreja em oração, que sempre fala no plural (gratias agimus, offerimus, petimus...), compondo o sacerdócio hierárquico que «celebra» por força de sua ordenação, com o sacerdócio dos fiéis que «con-celebram» em virtude de seu batismo (cf. abaixo, 2.1). O termo “concelebração» referido a vários ministros ordenados que copresidem a eucaristia, poderia ser, com vantagem, substituído por «copresidência». 
usar o plural em seu tesouro eucológico, como o Papa Francisco alude em seu discurso que constituiu o ponto de partida destas reflexões.

\section{A eucaristia, ação de Cristo, cabeça e membros}

Imediatamente após enumerar as formas da presença de Cristo nas ações litúrgicas, o Concílio prossegue ensinando que estas são ações do Cristo total, cabeça e membros:

Em tão grande obra, pela qual Deus é perfeitamente glorificado e os homens santificados, Cristo associa sempre a si a Igreja, sua esposa muito amada, a qual invoca o seu Senhor e por meio dele rende culto ao Eterno Pai. Com razão se considera a Liturgia como o exercício da função sacerdotal de Cristo. Nela, os sinais sensíveis significam e realizam, cada um à sua maneira, a santificação do homem e é exercido pelo Corpo Místico de Jesus Cristo, Cabeça e membros, o culto público integral (SC 7; DH 4007; grifos meus).

Também o Papa em seu discurso segue a mesma lógica, advertindo para um perigo que ele tem muito a peito, a clericalização, que acontece não só no cotidiano da Igreja, mas também - e talvez principalmente ou, em todo o caso, originariamente - nas celebrações litúrgicas em geral e na eucaristia em particular.

É frequente que o Papa admoeste contra a tentação do clericalismo, da centralização da Igreja no clero ou, até mesmo, na exclusão da dimensão eclesial de todos os batizados, se não em teoria, sim na prática. Mas parece ser a primeira vez que o faz com relação à liturgia. Com isso ele vai, de certa forma, à raiz do clericalismo, pois, no fundo, é graças à posição do clero na liturgia que se fundamenta toda outra exclusão dos não clérigos de uma atuação reconhecida no dia a dia da Igreja.

\subsection{A assembleia litúrgica celebra a eucaristia ${ }^{32}$}

Aludindo à etimologia da palavra "liturgia", o Papa inicia a explicitação desta parte de seu discurso aos participantes da $68^{\text {a }}$ Semana Litúrgica, dizendo:

\footnotetext{
${ }^{32}$ Cf. TABORDA, F. “A Constituição Sacrosanctum Concilium sobre a renovação da liturgia: avanços e perspectivas". Horizonte Teológico 12 (2013) pp. 9-27.
} 
"Por sua natureza a liturgia é, de fato, 'popular' e não clerical, sendo - como ensina a etimologia - uma ação para o povo, mas também do povo". Reforça essa reflexão a partir da lex orandi:

Como recordam tantas orações litúrgicas, é a ação que Deus mesmo realiza em favor de seu povo, mas também a ação do povo que ouve ao Deus que fala e reage louvando-o, invocando-o, acolhendo o inexaurível manancial de vida e de misericórdia que flui dos santos sinais ${ }^{33}$.

Que estas palavras valham também da eucaristia - e principalmente da eucaristia - atesta-nos o testemunho litúrgico de séculos, começando pelo próprio cânon romano (atual oração eucarística I) que mantém viva a consciência da participação ativa da assembleia na celebração. O texto da anamnese é claro: "Celebrando, pois, a memória... nós, vossos servos, e também vosso povo santo ... vos oferecemos..." (Unde et memores, Domine, nos servi tui et plebs tua sancta... offerimus).

São comuns comentários que chamam a atenção a esse texto, mesmo na Idade Média quando a forma litúrgica da eucaristia já se tinha clericalizado extremamente. Pedro Damião ( $\uparrow 1072)$, corajoso monge reformador da Igreja e do monacato, bispo de Óstia e cardeal, declarado Doutor da Igreja, escreve, comentando outro trecho do cânon romano que reza Pro quibus tibi offerimus, vel qui tibi offerunt hoc sacrificium (Pelos quais te oferecemos ou que te oferecem este sacrifício): "Nestas palavras fica patente que todos os fiéis, não só varões, mas também mulheres oferecem o sacrifício de louvor, embora pareça que só o sacerdote o oferece". ${ }^{34}$

Comentando as mesmas palavras do cânon, o Papa Inocêncio III (†1216) ensina: "Embora pareça que só um oferece o sacrifício, diz-se, no entanto, no plural 'oferecemos', porque o sacerdote não sacrifica só em sua pessoa, mas na pessoa de toda a Igreja"35. E acrescenta um pouco mais adiante: "Não somente os sacerdotes fazem a oblação, mas também todos os fiéis, porque aquilo que é feito especialmente pelo ministério dos sacerdotes, realiza-se de modo geral pela aprovação dos fiéis". ${ }^{36}$

33 PAPA FRANCISCO. "Audiência aos participantes da $68^{\mathrm{a}}$ Semana Litúrgica Nacional, 24.08.2017".

${ }^{34}$ PEDRO DAMIÃO. Undécimo opúsculo: livro que se intitula "O Senhor esteja convosco", para o eremita Leão. Cap. 8 (PL 145, 237). Grifo meu.

${ }^{35}$ INOCÊNCIO III. Seis livros sobre o sagrado mistério do altar, livro III, cap. 3 (PL 217, 844).

${ }^{36}$ INOCÊNCIO III. Seis livros sobre o sagrado mistério do altar, livro III, cap. 4 (PL 217, 845). 
Nisso esses autores medievais seguem a tradição dos Padres da Igreja que sabiam expressar com energia o mesmo princípio. João Crisóstomo (†407) é contundente:

Também o que diz respeito à oração eucarística é comum a ambos [ao sacerdote e ao povo]. Ele não pronuncia a oração eucarística por si só, mas também o povo todo [a apresenta com ele]. De fato, só depois de ter recebido a voz dos que consentem que é digno e justo ${ }^{37}$ fazêlo, só então ele dá início à oração eucarística. [...] Compreendamos que todos nós somos um só corpo e só nos distinguimos uns dos outros como os membros diferem entre si. Por isso não joguemos tudo sobre os ombros do sacerdote, mas também nós, enquanto parte do mesmo corpo, preocupemo-nos igualmente com toda a Igreja. Isso dá [aos sacerdotes] uma segurança maior, e a nós um maior crescimento. $^{38}$

E Teodoro de Mopsuéstia ( $\uparrow 428)$ chama quem preside a eucaristia de «língua comum da Igreja»:

Então, a assembleia se levanta num silêncio respeitoso, o pontífice oferece a oblação e imola o sacrificicio da comunidade. Um temor comum se abate sobre o pontífice e sobre todos nós, pela memória da morte que Nosso Senhor aceitou por nós, cujo memorial está por realizar-se neste sacrifício. Como o pontífice neste momento é a língua comum da Igreja, ele se serve nesta grandiosa liturgia das palavras mais adequadas. Ele louva a Deus, confessando que a Deus se devem os louvores e a glória, a adoração e o culto. ${ }^{39}$

$\mathrm{Na}$ esteira desses pensadores e de outros testemunhos, Ludovico Antonio

${ }^{37}$ Crisóstomo se refere ao diálogo invitatório da anáfora, quando, ao convite «Demos graças ao Senhor, nosso Deus» o povo responde «É digno e justo». Para nós este dado pode passar despercebido, porque, na tradução brasileira do missal, a resposta soa «É nosso dever e nossa salvação».

${ }^{38}$ JOÃO CRISÓSTOMO. Homilia 18 sobre a Segunda Epístola aos Coríntios (PG 61, 527).

${ }^{39}$ TEODORO DE MOPSUÉSTIA. "Homilia 16 (Segunda homilia sobre a missa)", 5. In: THÉODORE DE MOPSUESTE. Homélies catéchétiques, p. 270 (grifos meus). Na Homilia 15,36 , Teodoro já havia usado e explicado essa metáfora. Diz que o pontífice «é como o olho ou a língua. Como olho, vê as obras de todos e, com o cuidado que convém ao sacerdote, corrige e encaminha cada um segundo prescrito. Como língua, apresenta as orações de todos». Ib., p. 261 (grifo meu). 
Muratori $(\uparrow 1750),{ }^{40}$ grande historiador e pesquisador da Idade Média que se poderia considerar um precursor do Movimento Litúrgico, reassume a temática, demostrando a permanência dessa doutrina também depois da Reforma:

Deve-se, pois, saber que, embora de certo modo só o sacerdote sacrifique em nome de Cristo, da Igreja e do povo, contudo também o povo assistente tem parte nesse sacrificio e sacrifica juntamente com o ministro sagrado. Também ele faz tacitamente a oblação; também ele, com o afeto, acompanha as santas orações e preces do ministro, e o ministro as apresenta a Deus em nome próprio e ao mesmo tempo como embaixador dos assistentes. ${ }^{41}$

O Vaticano II recolhe esta tradição, quando proclama na Constituição Dogmática Lumen Gentium: «Os fiéis, em virtude de seu sacerdócio régio, concorrem para a oblação da eucaristia» [in oblationem Eucharistice concurrunt $=$ correm juntos] (LG 10).

O Papa Francisco corrobora na prática esta doutrina, ao preferir celebrar cotidianamente a eucaristia na Casa Santa Marta com a participação de fiéis e a copresidência de bispos e presbíteros, em vez de celebrar sozinho numa capela particular do Palácio Apostólico, com rara assistência de alguns privilegiados. Corresponde a essa atitude o que disse incisivamente na homilia da solenidade de Corpus Christi de 2017 e repetiu no discurso ora comentado: "A eucaristia não é um sacramento 'para mim', é o sacramento dos muitos que formam um só corpo, o santo povo fiel de Deus" ${ }^{2}$. Ele não só o afirma, mas fundamenta no clássico texto de Paulo na Primeira Carta aos Coríntios em que ensina: "Já que há um só pão, somos, embora muitos, um só corpo, pois todos participamos do único pão" (1Cor 10,17). E recalca a ideia ao acrescentar, usando uma de suas expressões criativas, segundo a qual a construção da unidade é o "DNA espiritual" do cristão: "A eucaristia é o sacramento da unidade. 'Quem a acolhe não pode ser senão artífice de unidade', porque nasce nele, em seu 'DNA espiritual', a construção da unidade'. ${ }^{43}$

${ }^{40}$ Cf. ENCICLOPEDIA TRECCANI. Verbete "Muratóri, Ludovico Antonio". Disponível em: $<$ http://www.treccani.it/enciclopedia/ludovico-antonio-muratori/>. Acesso em 30 de agosto de 2017.

${ }^{41}$ MURATORI, L. A. Della regolata divozione dei cristiani, cap. 16. Trento: Giambarista Parone Stamp. Vero, 1779, p. 177.

42 PAPA FRANCISCO. "Homilia na solenidade do Santíssimo Corpo e Sangue de Cristo. 18.06.2017'".

${ }^{43}$ PAPA FRANCISCO. "Homilia na solenidade do Santíssimo Corpo e Sangue de Cristo. 
A unidade se manifesta e se constrói quando o povo fiel, sob a presidência do ministro ordenado, concelebra a eucaristia, que é, por excelência, o sacramento da unidade eclesial. Falar da concelebração de toda assembleia litúrgica na eucaristia evoca a íntima relação entre Igreja e eucaristia, tão bem trabalhada por Henri De Lubac: "Como a eucaristia, a Igreja é um mistério de unidade - é, ainda, o mesmo mistério da Igreja, de riqueza inesgotável. Ambas são o corpo de Cristo - é ainda o mesmo corpo". ${ }^{44}$ Não há um hiato entre ambos. E o Cardeal prossegue: "É preciso entregar à compreensão dos dois mistérios, um pelo outro, até apreender em profundidade o Ponto de sua unidade".

Com isso já estamos no seguinte aspecto a ser salientado.

\subsection{A Igreja, corpo de Cristo a partir da eucaristia}

No longínquo 1963, o jovem teólogo Josef Ratzinger, então professor na Universidade de Münster (Alemanha), ensinava em suas preleções sobre a eucaristia uma verdade que ficara esquecida por muito tempo na mente e no coração dos fiéis católicos latinos. Ele dizia: "A meta suprema da eucaristia não é a transformação dos dons; os dons são sinais do que deve acontecer conosco. A meta suprema é a transformação dos seres humanos viventes no corpo de Cristo, na /sarx do Logos". ${ }^{45}$ E fundamentava esta afirmação em textos litúrgicos, o que, na época, não era habitual, mas hoje a volta ao axioma patrístico lex orandi - lex credendi ${ }^{46}$ tornou bastante usual.

Um possível ponto de partida para refletir sobre este ponto seria a dupla epiclese da anáfora alexandrina de Basílio. Eis o texto:

E te pedimos e invocamos, bom filantropo, Senhor, nós pecadores e indignos servos teus - e te adoramos -, para que, pelo beneplácito de tua bondade, venha teu Espirito Santo sobre Nós, teus servos, e sobre estes teus Dons apresentados, e [os] santifique e [os] manifeste como [mistérios] santos dos santos, e faça com que este Pão se torne o santo corpo do mesmo

18.06.2017".

${ }^{44}$ DE LUBAC, H. Méditation sur l'Église. Oeuvres completes 8. Paris: Cerf, 2006, p. 133.

${ }^{45}$ RATZINGER, J. Apostila das aulas sobre a eucaristia. Münster: ad instar manuscripti, 1963 (mimeo.), p. 96. Como era costume na Alemanha da época - pelo menos no caso dos professores mais eminentes - suas aulas foram gravadas, transcritas em estêncil, mimeografadas e divulgadas entre os interessados.

${ }^{46}$ Cf. TABORDA. O memorial da Páscoa do Senhor, pp. 23-39. 
nosso Senhor e Deus e salvador Jesus Cristo, para a remissão dos pecados e para a vida eterna para aqueles que dele participam, e que este CÁLICE [se torne] o precioso sangue da nova aliança do mesmo nosso Senhor e Deus e salvador Jesus Cristo, para a remissão dos pecados e para a vida eterna para aqueles que dele participam; e torna-nos dignos, Soberano, de participar de teus santos mistérios, para a santificação da alma, do corpo e do espírito, a fim de que nos transformemos num só corpo e num só espírito e encontremos parte e tenhamos herança com todos os santos,que, desde quando estavam no mundo, te foram agradáveis. ${ }^{47}$

Compare-se com a epiclese da anáfora de Crisóstomo:

Enviai o Espírito Santo sobre Nós e sobres estes Dons aqui presentes e fazei deste pão o precioso corpo de Cristo, e o que está neste cálice, o precioso sangue de Cristo, transformando-os pelo poder do Espírito Santo, para que estes Dons concedam aOS QUE DELES PARTICIPAM a lucidez de espírito, a remissão dos pecados, a comunhão com o Espírito Santo, a plenitude do reino do céu, a confiança perante Vós, e não sejam motivo de julgamento ou condenação. ${ }^{48}$

Se agora reduzimos esses textos a seu esquema básico, resulta:

Envia o teu Espírito sobre nós e sobre os dons apresentados para que transforme os dons no corpo sacramental, a fim de que, comungando, nós sejamos transformados no corpo eclesial.

Esses textos manifestam claramente a unidade que existe entre a transformação dos dons e a nossa transformação. A figura literária de elementos entrecruzados se chama quiasmo. Mas, no caso da epiclese das anáforas de Basílio e de Crisóstomo, o quiasmo não é só literário, senão também teológico. ${ }^{49} \mathrm{E}$ é teológico, porque explicita a finalidade da eucaristia.

${ }^{47}$ GIRAUDO, C. Num só corpo: tratado mistagógico sobre a eucaristia. $2^{\mathrm{a}}$ ed. São Paulo: Loyola, 2014, p. 303 (destaques meus).

${ }^{48}$ Segundo a tradução brasileira oficial da então Eparquia (agora Arquieparquia) Ucraniana de São João Batista (Curitiba, PR): COMISSÃO EPARQUIAL DE LITURGIA. Divina Liturgia de São João Crisóstomo. Curitiba: Estética Artes Gráficas, 1999, p. 63. Modifiquei a pontuação por ter omitido as rubricas e ressaltei os termos chave para a comparação e a reflexão subsequente.

${ }^{49}$ Cf. GIRAUDO, C. Num só corpo, p. 307. 
A eucaristia não foi instituída simplesmente para transformar o pão e o vinho no corpo e no sangue de Cristo. Ela não é necessária para "criar" presença de Cristo, pois ele já está realmente presente de muitas maneiras à sua Igreja e ao mundo. A finalidade da eucaristia é transformar-nos a nós no corpo eclesial de Cristo através da comunhão no corpo sacramental. Por isso, a eucaristia é o sacramento da unidade. É o que fica bem expresso na epiclese das anáforas de Basílio e de Crisóstomo. Não são duas transformações desvinculadas, autônomas, mas mutuamente relacionadas, interdependentes.

Nesse espírito, o Papa Francisco, na homilia da solenidade de Corpus Christi de 2013, faz uma pergunta crucial:

A eucaristia é o sacramento da comunhão, que nos faz sair do individualismo para viver juntos o seguimento, a fé nele. Agora devemos todos perguntar-nos diante do Senhor: como eu vivo a eucaristia? Vivo-a de modo anônimo ou como momento de verdadeira comunhão com o Senhor, mas também com todos os irmãos e irmãs que compartem desta mesma mesa $?^{70}$

Assim passamos ao terceiro ponto do discurso aqui comentado. A exegese e explanação deste item se dará quase exclusivamente a partir de textos do Papa Francisco. Vê-se que aqui ele toca um ponto que lhe está muito a peito: a vida do dia a dia do cristão comum, ou seja - para usar uma categoria que lhe é muito cara - do povo.

É a eucaristia, que se torna desde o início o centro e a forma da vida da Igreja. Mas pensamos também em todos os santos e santas - famosos ou anônimos - que se "repartiram" a si mesmos [spezzare], a própria vida, para "dar de comer" aos irmãos. Quantas mães, quantos pais, juntamente com o pão cotidiano, partido na mesa de casa, repartiram seu próprio coração para fazer crescer os filhos, e fazê-los crescer bem! Quantos cristãos, como cidadãos responsáveis, repartiram sua própria vida para defender a dignidade de todos, especialmente dos mais pobres, marginalizados e discriminados! Onde encontram a força para fazer tudo isto? Justamente na eucaristia: no poder do amor do Senhor ressuscitado. ${ }^{51}$

${ }^{50}$ PAPA FRANCISCO. "Homilia na missa na solenidade do Corpus Domini 30.05.2013" (grifo meu). Disponível em: <http:/w2.vatican.va/content/francesco/it/homilies/2013/documents/ papa-francesco_20130530_omelia-corpus-domini.html>. Acesso em 27 de agosto de 2017.

51 PAPA FRANCISCO. "Homilia na solenidade do Santíssimo Corpo e Sangue de Cristo. 26.05.2016". Disponível em: <http://w2.vatican.va/content/francesco/it/homilies/2016/documents/papa-francesco_20160526_omelia-corpus-domini.html >. Acesso em 27 de agosto de 2017. 


\section{A eucaristia, escola de vida cristã $\tilde{a}^{52}$}

Que a eucaristia nos transforma no corpo de Cristo não deve ser entendido num sentido meramente abstrato. Se somos o corpo de Cristo, somos hoje seus olhos para que, através de nós, ele veja as necessidades dos pobres, pequeninos, marginalizados, somos seus pés para que ele vá, por nosso meio, ao encontro dos necessitados, somos seus ouvidos para ouvir o clamor do povo, seu coração para sentir com "as alegrias e as esperanças, as tristezas e as angústias dos homens de hoje" (GS 1). E assim por diante. É justamente o que o Papa Francisco salienta na homilia de Corpus Christi de 2015: "Seremos seus olhos que vão em busca de Zaqueu e da Madalena; seremos sua mão que socorre os enfermos no corpo e no espírito; seremos seu coração que ama os necessitados de reconciliação, de misericórdia e de compreensão". ${ }^{53}$

Esta atitude de assumir-nos como corpo de Cristo não é óbvia. Na homilia da solenidade de Corpus Domini de 2013, refletindo sobre a multiplicação dos pães segundo Lucas, o Papa contrasta a solução "natural" dos discípulos com a proposta de Jesus: "Face à necessidade da multidão, eis a solução dos discípulos: cada um pense em si mesmo; despedir a turba!". Esta frase é repetida sem olhar o papel, como Francisco costuma fazer, quando quer acentuar um pensamento: "Cada um pense em si mesmo; despedir a turba!". E prossegue da maneira concreta que lhe é peculiar: "Quantas vezes nós cristãos temos essa tentação! Não assumimos a necessidade dos outros, despedindoos com um piedoso: 'Que Deus te ajude', ou com um não tão piedoso: 'Boa sorte', e se não nos virmos mais...”.

Depois passa a explicitar a solução de Jesus e deduzir dela o que nos cabe fazer hoje:

A resposta está no convite de Jesus aos discípulos "Dai vós mesmos...", "dar", partilhar. O que partilham os discípulos? O pouco que têm: cinco pães e dois peixes. Mas são justamente aqueles pães e aqueles peixes que nas mãos do Senhor alimentam toda a multidão. E são justamente os discípulos perdidos diante da incapacidade de seus meios, da pobreza do que podem pôr à disposição, que acomodarão o povo e distribuirão fiando-se na palavra de Jesus - os pães e peixes que alimentam a multidão.

${ }^{52}$ Cf. TABORDA, F. O memorial da Páscoa do Senhor, pp. 46-47.

53 PAPA FRANCISCO. "Homilia na solenidade do Corpo e Sangue de Cristo. 4.06.2015". Disponível em: <http://w2.vatican.va/content/francesco/it/homilies/2015/documents/papafrancesco_20150604_omelia-corpus-domini.html>. Acesso em 27 de agosto de 2017. 


\begin{abstract}
E isto nos ensina que na Igreja, mas também na sociedade, uma palavra chave de que não devemos ter medo é "solidariedade", isto é, saber pôr à disposição de Deus o que temos, nossas humildes capacidades, porque só na partilha, no dom, nossa vida será fecunda, dará fruto. Solidariedade: uma palavra mal vista pelo espírito mundano! $!^{54}$
\end{abstract}

Pode-se ver aqui a relação entre a eucaristia e uma "Igreja em saída", sonho do Papa Francisco. É o que está presente em sua mente na homilia pronunciada por ocasião dos cinquenta anos da primeira missa em italiano, presidida por Paulo VI na Paróquia Romana de Todos os Santos, na Via Ápia Nova, a 7 de março de 1965. Comemorando essa efeméride que pode ser considerada como o lançamento da reforma litúrgica, o Papa Francisco insiste na relação entre liturgia e vida.

A liturgia não é uma coisa estranha, lá, longínqua, e, enquanto se celebra, penso em muitas coisas, ou rezo o rosário. Não, não. Há uma correspondência entre a celebração litúrgica que depois transfiro para minha vida; e neste ponto se deve andar ainda mais adiante, se deve percorrer ainda um longo caminho. ${ }^{55}$

A propósito, ele recorda a Sacrosanctum Concilium, quando diz que a liturgia "é a primeira e necessária fonte na qual os fiéis bebem o espírito genuinamente cristão" (SC 14; DH 4014). E explica essa frase, dizendo que o culto litúrgico "não é uma doutrina a ser compreendida ou um rito a ser cumprido"; é também isso, mas muito mais: "é um manancial de vida e de luz para nossa caminhada de fé".

Essa caminhada se resume em nosso crescimento no corpo de Cristo e como corpo de Cristo. Nesta condição não podemos estar alheios às necessidades do próximo. Por isso, já na tradicional anáfora alexandrina de Basílio se pede que haja abundância de bens para podermos ajudar a quem precisa. Trata-se, pois, de uma consciência presente na melhor tradição litúrgica. Eis o texto da intercessão:

\footnotetext{
${ }^{54}$ PAPA FRANCISCO. "Homilia na Solenidade de Corpus Domini 30.05.2013".

${ }^{55}$ PAPA FRANCISCO. "Homilia na Paróquia Romana de Todos os Santos, na Via Ápia Nova, sábado 7.03.2015, missa do III domingo da quaresma". Disponível em: $<$ http://w2.vatican.va/ content/francesco/it/homilies/2015/documents/papa-francesco_20150307_omelia-parrocchia -ognissanti.html >. Acesso em 6 de setembro de 2017 (grifo meu).
} 
Bendize o ciclo do ano com tua benevolência, por causa dos pobres de teu povo, por causa da viúva e do órfão, por causa do forasteiro de passagem e do forasteiro residente, por causa de nós todos que esperamos em ti e invocamos teu santo Nome, pois os olhos de todos esperam em ti e tu lhes dás o sustento no tempo devido [...] Enche de júbilo e alegria nossos corações, para que, tendo sempre e em toda parte todo o necessário, abundemos em boas obras, para fazer tua santa vontade. ${ }^{56}$

Nessa anáfora não se pede prosperidade para os participantes da eucaristia, para que vivam tranquilos, felizes e contentes, mas para que eles, tendo os bens terrenos em abundância, possam socorrer os necessitados, preocupando-se com os segmentos mais fracos do tecido social: os pobres, as viúvas e os órfãos - que representam o suprassumo dos abandonados numa sociedade patriarcal -, os estrangeiros - detestados em sociedades xenófobas, como as de então e de hoje. O pedido de abundância de bens da terra visa não a nós que celebramos a eucaristia, mas aos que precisam de nosso socorro.

No mesmo espírito dessa venerável anáfora, a primeira e a quarta variantes da oração eucarística do Sínodo Suíço, acolhidas no Missal Romano, depois de revistas e corrigidas, sob o nome de «orações eucarísticas para diversas necessidades», pedem nas intercessões:

Dai-nos olhos para ver as necessidades e os sofrimentos dos nossos irmãos e irmãs; inspirai-nos palavras e ações para confortar os desanimados e oprimidos; fazei que, a exemplo de Cristo, e seguindo seu mandamento, nos empenhemos lealmente no serviço a eles. Vossa Igreja seja testemunha viva da verdade e da liberdade, da justiça e da paz, para que toda a humanidade se abra à esperança de um mundo novo. ${ }^{57}$

O que aqui é pedido evoca, em última análise, a relação entre eucaristia e lava-pés, tantas vezes evocada a partir do fato de o Evangelho de João narrar o lava-pés no momento em que os sinóticos contam a instituição da eucaristia. Essa relação foi resumida, de maneira muito feliz, pelo teólogo reformado

\footnotetext{
${ }^{56}$ Anáfora alexandrina de São Basílio. In: GIRAUDO, C. Num só corpo, p. 304 (grifos meus). Cf. também a anáfora de São Marcos, ib., pp. 359-361.

${ }^{57}$ Assim constava ainda no MISSALE ROMANUM. Editio typica tertia, pp. 690 e 705 (na primeira e na quarta variante dessa oração eucarística). Na edição emendada de 2008 determina-se omitir esse trecho nas páginas 690-691, mas não na página 705: cf. REIMPRESSIO emendata "Missalis Romani”. Notitiae no 503-504 (lug. - ago. 2008; nº 7-8), pp. 367-387 (aqui: p. 372).
} 
holandês, E. Van Waelderen, numa frase lapidar - quase um axioma: "Não há eucaristia sem lava-pés".

O Papa Francisco - quanto posso saber - nunca fez essa relação devido a sua opção de celebrar a Missa na Ceia do Senhor, da Quinta-feira Santa, com as pessoas mais desqualificadas da sociedade. As homilias nessas ocasiões se reduzem a poucas palavras introdutórias ao gesto do lava-pés, sem relacionar com a eucaristia.

Enrico Mazza apresenta uma sugestiva relação entre eucaristia e lava-pés ao comparar o mandato "Fazei isto em meu memorial", da narração da ceia em Paulo (1Cor 11,23.25) e Lucas $(22,19)$ com a ordem dada por Jesus em Jo 13,15 ("Dei-vos o exemplo, para que façais assim como eu fiz para vós"). O liturgista italiano defende que, no primeiro caso, é instituído um rito; no segundo, expresso o conteúdo do rito $^{58}$. Ora, o rito não pode ser separado do conteúdo. Vale dizer: também para ele não há eucaristia sem lava-pés.

Voltando à opção de Francisco de celebrar a Missa in Coena Domini entre os últimos, os descartados, pode-se dizer que ele expressa com gestos o que os teólogos citados disseram com palavras: a ceia do Senhor só pode ser compreendida no gesto de valorizar e acolher os últimos. Sem isso pode tornar-se um rito vazio.

\section{Considerações finais}

De 25 a 27 de fevereiro de 2015, realizou-se na Universidade Gregoriana, de Roma, sob os auspícios da Conferência Episcopal Italiana, um Simpósio sobre "Liturgia e evangelização". Em nome do Papa, o Secretário de Estado, Cardeal Pietro Parolin, enviou uma mensagem, expressando a visão de Francisco:

Que o Simpósio suscite renovada consciência do caráter evangelizador da liturgia, cuja eficácia pastoral requer também a ars celebrandi entendida como capacidade de fazer palpitar no coração das pessoas o coração de Deus, isto é, sua graça, sua misericórdia e seu amor. ${ }^{59}$

\footnotetext{
${ }^{58}$ Cf. MAZZA, E. Il Nuovo Testamento e la Cena del Signore. Bologna: Edizione Dehoniane, 2017, pp. 157-159 e passim.

59 "Messagio del Sommo Pontefice". In: MAGNANI, F.; D’ADAMO, V. (Orgs.). Liturgia ed evangelizzazione: la Chiesa evangelizza con la bellezza della liturgia. Soveria Manelli: Rubbettino, 2016, p. 20.
} 


\section{Referências bibliográficas}

AMBROISE DE MILAN. Des sacrements. Des mystères. Sources Chrétiennes n. 25. Paris: Cerf, 1950 (Sigla: SChr 25).

AMBROSIO DE MILÃO. Os sacramentos e os mistérios. Petrópolis: Vozes, 1972.

AUGUSTIN, G. La Chiesa secondo Papa Francesco. Milano: Paoline, 2016.

CODINA, V. "Não extingais o Espírito" (1Ts 5,19): iniciação à pneumatologia. São Paulo: Paulinas, 2010.

COMISSÃO EPARQUIAL DE LITURGIA. Divina Liturgia de São João Crisóstomo. Curitiba: Estética Artes Gráficas, 1999.

CONGREGAÇÃO DO CULTO DIVINO E DA DISCIPLINA DOS SACRAMENTOS. "Instrução Redemptionis Sacramentum, de 25.03.2004". Disponível em: <http://www.vatican.va/roman_curia/ congregations/ccdds/documents/rc_con_ccdds_doc_20040423 redemptionis-sacramentum_lt.html>. Acesso em 30 de agosto de 2017.

D’AMBROSIO, R. Ce la fará Francesco? La sfida della riforma ecclesiale. Molfetta (BA): La Meridiana, 2016.

DE LUBAC, H. Méditation sur l'Église. Oeuvres completes 8. Paris: Cerf, 2006.

DENZINGER, Heinrich; HÜNERMANN, Peter (ed.). Compêndio dos símbolos, definições e declarações de fé e moral. $2^{\text {a }}$ edição brasileira, revisada e ampliada de acordo com a 43 a edição (2010). São Paulo: Paulinas; Loyola, 2013.

EISENBACH, F. Die Gegenwart Jesu Christi im Gottesdienst: systematische Studien zur Liturgiekonstitution des II. Vatikanischen Konzils. Mainz: Matthias-Grünewald, 1982.

ENCICLOPEDIA TRECCANI. Verbete "Muratóri, Ludovico Antonio". Disponível em: $<$ http://www.treccani.it/enciclopedia/ludovico-antoniomuratori/>. Acesso em 30 de agosto de 2017.

FRANÇA MIRANDA, M. A reforma de Francisco: fundamentos teológicos. São Paulo: Paulinas, 2017.

GIRAUDO, C. Num só corpo: tratado mistagógico sobre a eucaristia. $2^{\mathrm{a}}$ ed. São Paulo: Loyola, 2014. 
GONZÁLEZ-QUEVEDO, L. O novo rosto da Igreja: Papa Francisco. $4^{\mathrm{a}} \mathrm{ed}$. corrigida e ampliada. São Paulo: Loyola, 2015.

IGNACE D'ANTIOCHE. Lettres. Martyre de Polycarpe. Sources Chrétiennes n. 10. $3^{\mathrm{e}}$ édition. Paris: Cerf, 1958 (Sigla: SChr 10).

INÁCIO DE ANTIOQUIA. Cartas de Santo Inácio de Antioquia: comunidades eclesiais em formação. $2^{\mathrm{a}}$ ed. Petrópolis: Vozes, 1978.

JUNGMANN, J. A. Missarum sollemnia: origens, liturgia, história e teologia da missa romana. $2^{\mathrm{a}}$ ed. Petrópolis: Vozes, 2010.

KONINGS, J. “Quem é quem na 'parábola do último juízo' (Mt 25, 31-46)?”. Perspectiva Teológica 10 (1978), pp. 367-402.

LITURGIA DAS HORAS segundo o rito romano. Vol. IV. Petrópolis/São Paulo: Vozes/Paulinas/Paulus/Ave-Maria, 1999.

MAGNANI, F.; D'ADAMO, V. (Orgs.). Liturgia ed evangelizzazione: la Chiesa evangelizza con la bellezza dreimpreella liturgia. Soveria Manelli: Rubbettino, 2016.

MARLIANGEAS, B. D. Clés pour une théologie du ministère: in persona Christi, in persona Ecclesiae. Paris: Beauchesne, 1978.

MAZZA, E. Il Nuovo Testamento e la Cena del Signore. Bologna: Edizione Dehoniane, 2017.

MIGNE, J.-P. Patrologia Series Graeca. Vol. 1-161. Paris: Migne, 1857-1866.

MIGNE, J.-P. Patrologiae Cursus Completus: Patrum Latinorum. Vol. 1-221. Paris: Migne, 1844-1855.

MISSALE ROMANUM. Editio typica tertia. Città del Vaticano: Libreria Editrice Vaticana, 2002.

MURATORI, L. A. Della regolata divozione dei cristiani. Trento: Giambarista Parone Stamp. Vero, 1779.

PAPA FRANCISCO. "Audiência aos participantes da $68^{\mathrm{a}}$ Semana Litúrgica Nacional, 24.08.2017”. Disponível em: <http://press.vatican.va/content/ salastampa/it/bollettino/pubblico/2017/08/24/0531/01182.html>. Acesso em 25 de agosto de 2017.

PAPA FRANCISCO. "Homilia na festa do Santíssimo Corpo e Sangue de Cristo, 18.06.2017". Disponível em: <http://w2.vatican.va/content/ 
francesco/it/homilies/2017/documents/papa-francesco_20170618_ omelia-corpus-domini.html>. Acesso em 27 de agosto de 2017.

PAPA FRANCISCO. "Homilia na Paróquia Romana de Todos os Santos, na Via Ápia Nova, sábado 7.03.2015, missa do III domingo da quaresma”. Disponível em: <http://w2.vatican.va/content/francesco/ it/homilies/2015/documents/papa-francesco_20150307_omeliaparrocchia-ognissanti.html>. Acesso em 6 de setembro de 2017.

PAPA FRANCISCO. "Homilia na Solenidade do Corpo e Sangue de Cristo. 4.06.2015". Disponível em: <http://w2.vatican.va/content/francesco/it/ homilies/2015/documents/papa-francesco_20150604_omelia-corpusdomini.html>. Acesso em 27 de agosto de 2017.

PAPA FRANCISCO. "Homilia na Solenidade de Corpus Domini 30.05.2013”. Disponível em: <http://w2.vatican.va/content/francesco/ it/homilies/2013/documents/papa-francesco_20130530_omelia-corpusdomini.html>. Acesso em 27 de agosto de 2017.

PAPA FRANCISCO. "Homilia na Solenidade do Santíssimo Corpo e Sangue de Cristo. 26.05.2016". Disponível em: <http://w2.vatican. $\mathrm{va} /$ content/francesco/it/homilies/2016/documents/papa-francesco_ 20160526_omelia-corpus-domini.html>. Acesso em 27 de agosto de 2017.

PAPA FRANCISCO. "Misericordiae vultus". Disponível em: <http:// w2.vatican.va/content/francesco/pt/apost_letters/documents/papafrancesco_bolla_20150411_misericordiae-vultus.html >. Acesso em 23 de novembro de 2017.

PAPA PAULO VI. "Christus dominus". Disponível em: <http://www. vatican.va/archive/hist_councils/ii_vatican_council/documents/vatii_decree_19651028_christus-dominus_po.html >. Acesso em 23 de novembro de 2017.

PAPA PAULO VI. "Encíclica Mysterium fidei, 03.09. 1965”. Disponível em: $<$ http://www.vatican.va/holy_father/paul_vi/encyclicals/documents/ hf_p-vi_enc_03091965_mysterium_po.html $>$. Acesso em 30 de setembro de 2012.

PARENTI, S.; VELKOVSKA, E. “'Re celeste, Paraclito, Spirito di Verità': il Veni Creator Spiritus della liturgia bizantina”. In: CARR, E. (Ed.). 
Spiritus spiritalia nobis dona potenter infundit: a proposito di tematiche liturgico-pneumatologiche. Studi in onore di Achille M. Triacca, sdb. Roma: Centro Studi S. Anselmo, 2005, pp. 387-404.

RATZINGER, J. Apostila das aulas sobre a eucaristia. Münster: ad instar manuscripti, 1963 (mimeo).

REIMPRESSIO emendata "Missalis Romani". Notitiae no 503-504 (lug. ago. 2008; $\mathrm{n}^{\mathrm{o}}$ 7-8), pp. 367-387.

SPERANDIO, J. M.; TAMANINI, P. A. (Orgs.). Liturgikon: próprio das principais festas. Teresina: EDUFPI, 2015. Disponível em: $<$ https:// www.ecclesia.com.br/biblioteca/liturgia/liturgikon2.pdf $>$. Acesso em $1^{\circ}$ de setembro de 2017.

TABORDA, F. Cristianismo e ideologia: ensaios teológicos. São Paulo: Loyola, 1984.

TABORDA, F. Nas fontes da vida cristã : uma teologia do batismo-crisma. $3^{\text {a }}$ edição revisada. São Paulo: Loyola, 2012.

TABORDA, F. “A Constituição Sacrosanctum Concilium sobre a renovação da liturgia: avanços e perspectivas”. Horizonte Teológico 12 (2013), pp. 9-27.

TABORDA, F. O memorial da Páscoa do Senhor: ensaio litúrgico-teológicos sobre a eucaristia. $2^{\text {a }}$ ed. São Paulo: Loyola, 2015.

TABORDA, F. A Igreja e seus ministros: uma teologia do ministério ordenado. $2^{\mathrm{a}}$ reimpressão. São Paulo: Paulus, 2016.

TABORDA, F. "Penitência cotidiana: uma verdade a ser recordada". Revista Eclesiástica Brasileira 76 (2016), pp. 402-427.

THEISSEN, G. Sociologia da cristandade primitiva: estudos. São Leopoldo: Sinodal, 1985.

TEODORO DE MOPSUÉSTIA. "Homilia 15 (Primeira homilia sobre a missa)". In: THÉODORE DE MOPSUESTE. Homélies catéchétiques. Paris: Migne, 1996, p. 261.

VATICANO II. “Ad gentes”. Disponível em: $<$ http://www.vatican.va/archive/ hist_councils/ii_vatican_council/documents/vat-ii_decree_19651207_ ad-gentes_po.html >. Acesso em 23 de novembro de 2017.

VATICANO II. "Gaudium et spes". Disponível em: <http://www. 
vatican.va/archive/hist_councils/ii_vatican_council/documents/vatii_const_19651207_gaudium-et-spes_po.html >. Acesso em 23 de novembro de 2017.

VATICANO II. "Lumen gentium". Disponível em: <http://www.vatican. va/archive/hist_councils/ii_vatican_council/documents/vat-ii_ const_19641121_lumen-gentium_po.html >. Acesso em 23 de novembro de 2017.

VATICANO II. "Sacrosanctum concilium". Disponível em: <http://www. vatican.va/archive/hist_councils/ii_vatican_council/documents/vat-ii_ const_19631204_sacrosanctum-concilium_po.html >. Acesso em $23 \mathrm{de}$ novembro de 2017.

Francisco Taborda

Doutor em Teologia pela Westfälische Wilhelms-Universität Münster

(Alemanha)

Professor emérito de Teologia da Faculdade Jesuíta de Filosofia e Teologia (FAJE)

Belo Horizonte / MG - Brasil

E-mail: prof.ftaborda@gmail.com

Recebido em: 28/10/17

Aprovado em: 30/11/17 